\title{
Antonino Di Vita
}

Antonino Di Vita was born at Chiaramonte Gulfi (Ragusa, Sicily) on 19 October 1926 and passed away, quite suddenly, at Rome on 22 October 2011, struck down by an inexorable illness.

Of the three great lines of research pursued by Di Vita, only one is directly pertinent here, that concerning the history and archaeology of Libya, and I will focus on this. However, the other two cannot be ignored: the archaeology of Sicily, which marked his youth, and that of Gortyn on Crete, which characterised his mature years. It will be a brief list of enterprises, stark like all lists, which says little of the personality of Nino Di Vita, but a great deal of the positive scientific results achieved and of his civic commitment.

A student of Santo Mazzarino and Guido Libertini, he graduated at the University of Catania in 1947. He completed the Diploma of Specialisation at the Scuola Nazionale di Archeologia at Rome in 1951, after a year (1950) as student at the Italian Archaeological School at Athens, where Doro Levi was then director. Di Vita was assistente in Classical Archaeology at the University of Palermo in 1951-1955, teaching the subject between 1951 and 1953. After that, he entered the employment of the Soprintendenza alle Antichità as an archaeological inspector, working first at Syracuse, then at Rome (Southern Etruria) and finally at Florence. From 1958 he was a freelance teacher of Archaeology and of Greek and Roman Art History, and then taught these subjects, together with Ancient Topography, at the University of Perugia. From 1968 to 2001 he held the professorship of Classical Archaeology at the University of Macerata. There he was Dean of the Faculty of Letters from 1970 to 1974, then pro-Vice-Chancellor and eventually Vice-Chancellor from 1974 to 1977. From 1977 to 2000 he was Director of the Italian Archaeological School of Athens. In the years between 1962 and 1965 he was Adviser to the Libyan Government for the Antiquities of Tripolitania. In 2004 he was made Emeritus Professor at the University of Macerata, and from 2005 onwards he was Director there of the Centro di documentazione e ricerca sull'archeologia dell'Africa settentrionale.

Let us turn now to Libya, our Libya, where I had arrived before him in 1955 at the side of Renato

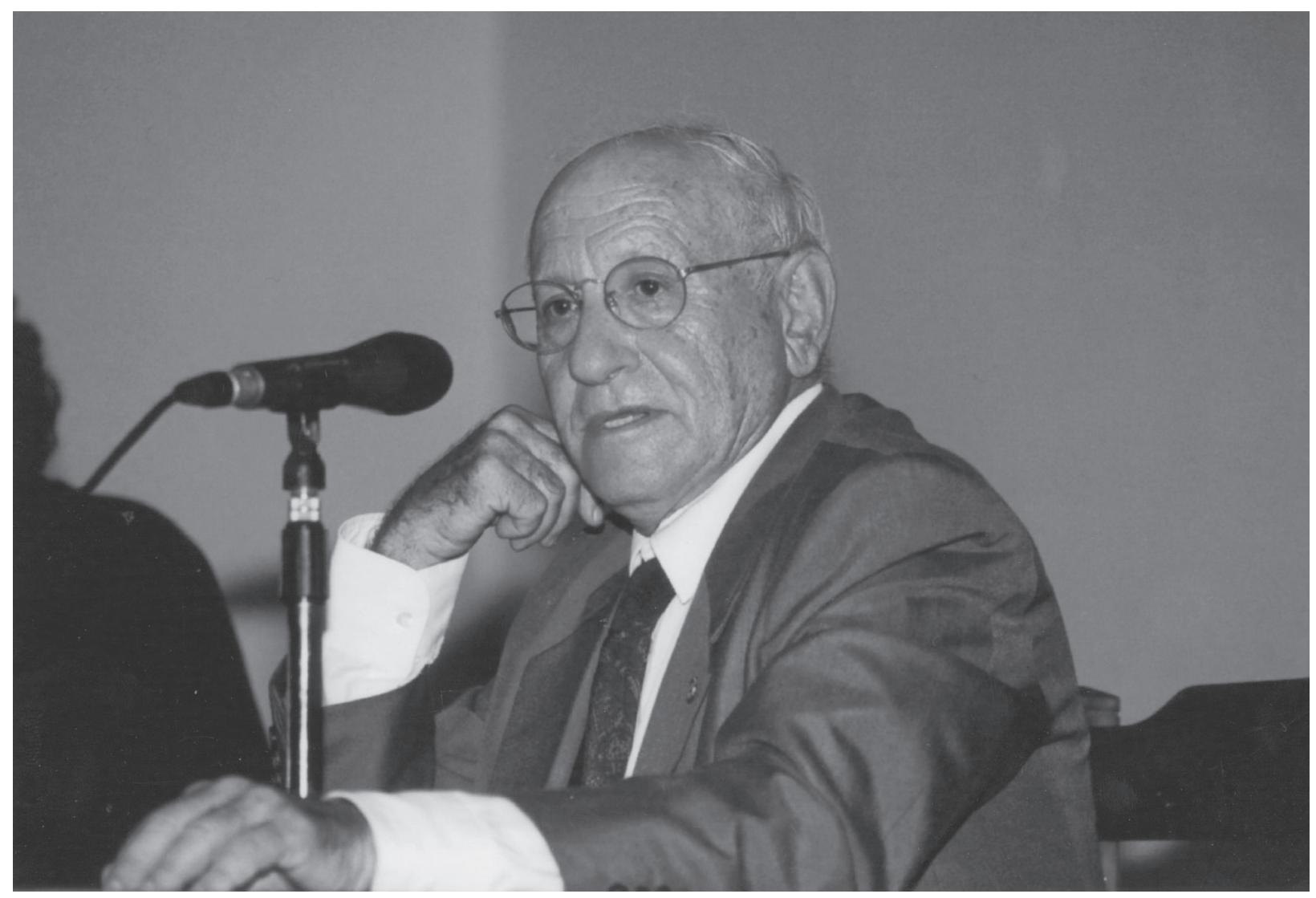

Antonino di Vita (photo courtesy of Maria Antonietta Rizzo-Di Vita). 


\section{OBITUARIES}

Bartoccini. I do not know exactly what guided the decision of Nino Di Vita, in the years 1962-1965, when he carried out in Libya, particularly at Sabratha, his duties as the last Italian Adviser at the Department of Antiquities at Tripoli following the sudden death of Ernesto Vergara Caffarelli. It certainly was not, only, the invitation put his way by our distinguished teachers, it was certainly not the search for glory and least of all for financial security. I like to think that he went to Libya with his experiences in the western Punic world on Sicily (especially at Selinunte) in mind, and with a specific agenda. Otherwise it would be difficult to explain his swift, concrete and successful work at Sabratha. Apart from the above, without doubt, other essential motives drove him towards the North African coast. Perhaps he also went in search of himself, following his experience of the formality and ephemeral nature of university life, for until the end of his life he called himself a 'Superintendency archaeologist'.

In 1963-64, together with Richard G. Goodchild, Di Vita founded at Tripoli the well-known journal Libya Antiqua, of which the fifth volume of the new series was published in 2010, edited by Di Vita and Salah R. Aghab. The results that he achieved, particularly at Sabratha, are notable. These included fieldwork conducted with strict attention to stratigraphy in Regio VI; excavation, study and reconstruction of the Punic Mausoleum B, a very rare example of the architecture of the Punic-Hellenistic baroque, some $26 \mathrm{~m}$ high, a subject to which he returned several times, constantly refining his opinions, and collaboration in the creation of the successful Punic Museum, an unicum in Mediterranean Africa, where the original fragments of Mausoleum B are exhibited. He was also responsible for the excavation and conservation of the villa of the 'Gara delle Nereidi' near Tajura, with a sophisticated mosaic of classical inspiration; excavation of parts of the tophet of Punic Sabratha, with the support of his Libyan colleagues, resulting in a number of exceptional finds, especially carved stelai; study and restoration of several painted tombs, notably that 'of the Gorgon' and that 'of the Heroicised Departed', of the first half of the first century $\mathrm{AD}$. He carried out careful research and accurate restoration of the extensive open-air sacred and funerary precinct of Sidret el-Balik, in the centre of modern day Sabratha, which includes an important complex of paintings of the middle of the fourth century $\mathrm{AD}$ (almost $180 \mathrm{sq} \mathrm{m}$ of paintings decorating the walls of a rectangular area where the members of a clan met to hold banquets at the tomb of an ancestor). Di Vita devoted passionate care over many years, not only to the excavation but also to the definitive conservation of the area, and to the difficult restoration of the wall-paintings.

At Lepcis Magna, besides the laborious study of the Serapeum, now nearly completed, he organised a work and study group with the architects Niccolò Masturzo and Maria Ricciardi (later joined by Giorgio Rocco and Monica Livadiotti). The group worked towards a complete revision of the early excavation results in the Old Forum, in particular the study, documentation and publication of the three temples on the north-east side.

The hardest task was without doubt the completion of the restoration of the Arch of Septimius Severus: begun by Sandro Stucchi in 1966 and continued by Lidiano Bacchielli after Stucchi's death, the project was completed by Di Vita. The most thankless work was the search for and the assembly of the innumerable decorative marble fragments scattered over a remarkably large area since late antiquity, when the monument had collapsed on itself. Unfortunately, for purely political reasons Nino Di Vita did not have the satisfaction of seeing the inauguration of the monument, for which he had prepared interpretative panels, and it is probable that this work, on which both Italian and Libyan scholars and technicians had collaborated for decades, will continue to remain in the shadows.

Let us return to the beginning, to Sicily: to Ragusa, Camarina and Selinunte - starting with his Sicilian roots, from Ragusa, tied to the family and island traditions. When I introduced at Ragusa Di Vita's beautiful book, Da Siracusa a Mozia. Scritti di Archeologia Siciliana (Padova 1998), I emphasised that he had always been 'Sicilian': not a famous Sicilian who had returned to the island for the occasion, not a dear but long-lost friend: he had always remained in touch with his land, cultivating his persona as a proud and well-educated provincial (as only the province of Sicily knows how to do). For this reason, in his work Sicily appears like the metaphor for a vital world; never lost, but occasionally forsaken and constantly desired. Di Vita suffered a regret, never assuaged, for the excavations and for the Ragusan province, that he had left for Perugia, Rome and then Libya; a burning regret, as he wrote in 1995 in the captivating personal note 'Camarina Revisited' in his introduction to the Guide to the Archaeological Museum. But his testimony - and I refer in particular to the touching pages, also from 1995, of 'Remembering Ragusa' - allowed him to elevate the tone of his youthful memories, run through by virile melancholia, to the status of a collective memory.

Like that of Chiaramonte, the archaeological theme of Selinunte also matured at Palermo, starting 


\section{OBITUARIES}

what would become an intense season of collaboration between the Istituto di Archeologia of the University of Palermo and the Soprintendenza of western Sicily. In the first instance there were the important results obtained from the trenches to the south-east of the great terrace to the east of Temples $\mathrm{C}$ and $\mathrm{D}$, excavations that were concentrated in only two houses of the fourth century $\mathrm{BC}$, but which allowed Di Vita to draw a series of significant conclusions on the Punic element at Selinunte in the fourth and third centuries BC, filling in the apparent hiatus between classical and Hellenistic Selinunte. Those conclusions, perhaps a little bold inasmuch as they were based on a limited collection of data, were received with some suspicion. However, nearly a decade later the work of J. Bovio Marconi and Vincenzo Tusa fully vindicated them.

In 1967 there appeared an excellent monograph by Di Vita, Per l'architettura e l'urbanistica greca d'età arcaica: la stoà del temenos del Tempio C e lo sviluppo programmato di Selinunte. It was the first time that anyone looked with breadth of vision and a full grasp of the evidence from the excavations at the growth of the great Megarian colony in the archaic period. Through it one could witness the emergence, in the decades around the middle of the sixth century $\mathrm{BC}$, of the strong personality of the architect and unknown inventor of an L-shaped stoa. Selinunte was no longer to be seen as a colony (like Himera, but for different reasons); not as a colony with a political-military rationale of opposing the Phoenicians, but as a city founded without frontiers, open to commerce with the Mediterranean and the Tyrrhenian Seas, a truly permanent 'trade-point' of extraordinary impact. This was, once again, a new interpretation, to explain the lightning economic growth of Selinunte.

Let us turn briefly to Di Vita's two decades of activity in Greece, as Director of the Scuola Archeologica Italiana di Atene, and in particular to the resumption of the Italian excavations at Gortyn, on Crete. His prestigious nomination as Director inevitably presaged a change of direction, and this could only be towards Gortyn, an archaeological and historical focal point of the Mediterranean. Like Sicily, this was another great island in the life of Di Vita. His tenure at the School ended in 2000 with a crowning acclamation at the end of the very successful conference in Heraklion on 'Roman and Proto-Byzantine Crete' (Creta Romana e Protobizantina). A little more than a decade later, at the Accademia dei Lincei on the evening of the 11 February 2011, I had the privilege of coordinating and presenting, together with my own, the interventions of our colleagues Enzo Lippolis and Jean-Pierre Sodini on the volume by Di Vita Gortina di Creta. Quindici secoli di vita urbana (Roma 2010). I spoke of Gortyn and of Nino Di Vita, following the publication of the masterly volumes on the excavations at Gortyn (volumes I-VI, 1988-2004). The publication of this book offers us a memorable cross-section of the history of the capital city that was Gortyn, through 'fifteen centuries of urban life', encompassing almost a quarter-century of research and teaching by Di Vita in Greece.

This was Antonino Di Vita, my unforgettable friend and colleague.

Nicola Bonacasa 